Федеральное государственное автономное учреждение здравоохранения

Больница Пущинского научного центра Российской академии наук

Н.И. Косякова, М.В. Акуленко, И.Э. Сероштанова, В.С. Балясникова, Э.Л. Ильеня, Е.В. Панкратова, Л.А. Андреева

\title{
ИНДИВИДУАЛЬНЫЕ ОСОБЕННОСТИ ТКАНЕВОГО ЭНЕРГООБМЕНА И ИХ РОЛЬ В РАЗВИТИИ МИТОХОНДРИАЛЬНОЙ ДИСФУНКЦИИ ПРИ ЗАБОЛЕВАНИЯХ РЕСПИРАТОРНОГО ТРАКТА У ДЕТЕЙ
}

Методические рекомендации

по внедрению результатов научно-поисковой работы 
УДК 616.24-053.2-612.013.7: 616-008.9

ББК 53.0/57.8616.2

K71

Согласовано Научно-координационньй совет БПНЦ РАН.

Протокол №20 om 18.09.2020 г.

Косякова Н.И., Акуленко М.В., Сероштанова И.Э., Ильеня Э.Л., Балясникова В.С., Панкратова Е.В., Андреева Л.А.

К71 Индивидуальные особенности тканевого энергообмена и их роль в развитии митохондриальной дисфункции при заболеваниях респираторного тракта у детей: методические рекомендации по внедрению результатов научно-поисковой работы / Н.И. Косякова, М.В. Акуленко, И.Э. Сероштанова, В.С. Балясникова, Э.Л. Ильеня, Е.В. Панкратова, Л.А. Андреева. - М.: Издательский дом Академии Естествознания, 2021. $-28 \mathrm{c}$.

\section{ISBN 978-5-91327-684-1 \\ DOI 10.17513/np.461}

В методических рекомендациях изучены особенности дисфункции митохондриальных ферментов у детей с патологией респираторного тракта. Полученные данные об активностях сукцинатдегидрогеназы (СДГ) и лактатдегидрогеназы (ЛДГ) в лимфоцитах периферической крови, отражающие активность митохондриального дыхания и гликолиза, а также параметры распределения клеточной популяции по активностям ферментов отражали тяжесть течения заболевания: при легком течении бронхиальной астмы и у детей группы ЧДБ наблюдалось увеличение активности окислительного фосфорилирования, сопровождающееся также поддержкой в виде активации гликолиза. При бронхиальной астме средней степени тяжести наблюдались гиперактивация митохондриального дыхания при отсутствии или угнетении процессов гликолиза; в группе детей с тяжелым течением бронхиальной астмы с сопутствующими заболеваниями наблюдалась депрессия всех изучаемых дегидрогеназ, что, вероятно, является неблагоприятным прогностическим признаком. Полученные результаты исследования позволили своевременно вносить коррекцию в терапию детей с респираторной патологией.

Полученные данные исследования могут быть использованы в работе врачейпедиатров, ЛОР-врачей, иммунологов-аллергологов как в амбулаторных условиях, так и в условиях стационаров.

ISBN 978-5-91327-684-1
(С) Н.И. Косякова, М.В. Акуленко, И.Э. Сероштанова, В.С. Балясникова, Э.Л. Ильеня, Е.В. Панкратова, Л.А. Андреева, 2021

(c) ИД «Академия Естествознания»

(C) $\mathrm{AHO}$ «Академия Естествознания» 


\section{СОДЕРЖАНИЕ}

Введение ....................................................................................... 4

Материалы и методы исследования ............................................................. 7

Измерение активности дегидрогеназ в мазках крови ..................................9

Результаты исследования и их обсуждение.

Показатели энергетического обмена при астме ................................... 11

Анализ популяций лимфоцитов по активности митохондриального дыхания и гликолиза …........................................ 16

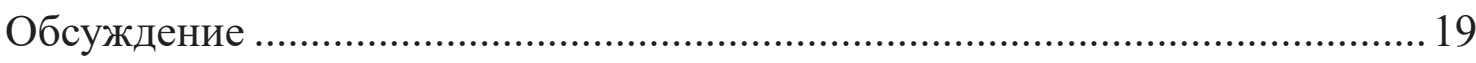

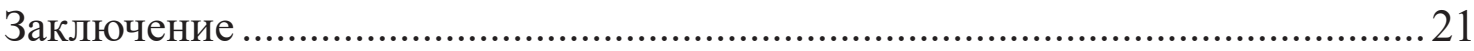

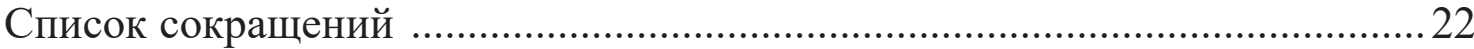

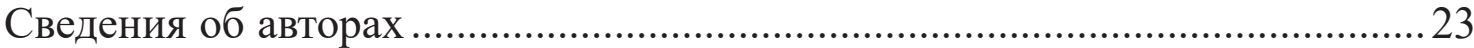

Перечень опубликованных работ, выступлений, наличие патента по теме методических рекомендаций за последние три года..............224

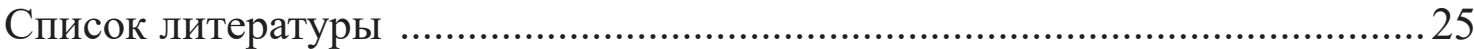




\section{ВВЕДЕНИЕ}

Практически до конца 20 века биоэнергетика была одним из разделов фундаментальной биологии и не выходила за рамки лабораторной науки. Теперь же накопленный опыт экспериментов на животных стал активно внедряться в клиническую практику. В медицинскую терминологию активно входят такие понятия, как «нарушения клеточного энергообмена», «дисфункции митохондрий» и «метаболическое здоровье». Биоэнергетика во главе с митохондриями стала центральным объектом для понимания механизмов прогрессирования болезни и развития новых терапевтических стратегий. «Оптимальное функционирование клеточной энергетики - ключ к здоровью» становится девизом современной биомедицины. Расширился круг заболеваний с так называемыми «вторичными» (т.е. не связанными с генетическими поломками митохондрий) нарушениями клеточного энергообмена. Доказано, что такие кажущиеся разными болезни, как диабет, атеросклероз, нейродегенеративные заболевания, имеют общий патофизиологический механизм - митохондриальную дисфункцию [1-8].

Постепенно накапливаются данные, что и при болезнях легких патологическим признаком, который появляется на ранних стадиях и развивается последовательно, являются нарушения клеточной биоэнергетики [9-13]. Бронхиальная астма (БА) - хроническое заболевание, которое характеризуется постоянными воспалительными процессами и частично обратимой обструкцией верхних дыхательных путей. Вредные факторы окружающей среды, такие как табачный дым, выхлопные газы и пр., являются высоко окисляющими по своей природе и вызывают повреждения легких в результате окислительного стресса $[14 ; 15]$. Именно окислительный стресс является одним из ведущих факторов в патогенезе астмы. Хорошо известно, что митохондрии - главные сенсоры окислительного стресса и воспаления в клетке; также эти органеллы играют важную роль при адаптивном иммунном ответе лимфоцитов в дыхательных путях и легочной ткани и регулировании клеточного воспалительного ответа [16]. Повреждение биоэнергетики наряду с увеличением производства активных форм кислорода в митохондриях и повреждением эпителия дыхательных путей стало новым ключевым аспектом патогенеза заболеваний респираторного тракта [17].

Таким образом, выявление нарушений клеточного энергообмена индивидуума становится необходимым для медицины 21 века, но в настоящее время разработано очень мало клинических тестов, позволяющих оценить этот параметр. Биопсия мышц, культуры фибробластов (кожи) или лим- 
фоидные клеточные линии в сочетании с полярографическими исследованиями выделенных митохондрий были материалами и методами выбора в биохимических исследованиях, но в качестве рутинных и доступных процедур для стандартной клинической лаборатории они не приемлемы. Еще в 1960-х гг. советский ученый Р.П. Нарциссов показал, что лимфоциты периферической крови можно рассматривать не только как клетки специальной иммунной защиты, но и как элементы единой информационной системы, отражающей состояние организма [18;19]. Однако его исследования не получили широкого распространения за рубежом, и только в последнее десятилетие начали появляться независимые исследования зарубежных коллег о том, что множество патологий, которые клинически проявляются симптомами преимущественно в одном органе, таком как, например, мозг, сердце или легкие, также могут модулировать энергетику митохондрий в циркулирующих лимфоцитах крови [20-24]. Хорошо известно, что лимфоциты крови постоянно подвергаются воздействию множества факторов, ассоциированных с метаболическим стрессом, и отвечают на системные метаболические и воспалительные стрессоры. Вероятно, поэтому они и могут служить функциональными биомаркерами для клинической биоэнергетики, являясь при этом идеальными объектами для исследований. Таким образом, мониторинг биоэнергетики иммунных клеток может стать диагностическим инструментом для количественной оценки митохондриальных функций и общего биоэнергетического здоровья индивидуума.

В лаборатории энергетики биологических систем ФГБУН ИТЭБ РАН был разработан новый подход к диагностике функциональных состояний с помощью оригинального метода, названного ЦБХ [25]. В качестве биомаркеров процессов переключения путей окисления в лимфоцитах периферической крови измеряются два фермента: сукцинатдегидрогеназа (СДГ) - как показатель активности митохондриального дыхания и лактатдегидрогеназа (ЛДГ) как показатель одного из восстановительных путей поддержания биосинтезов - гликолиза [26-28].

Цитобиохимический метод позволяет оценить соотношение активности митохондрий и гликолиза в лимфоцитах крови пациента и создан специально, чтобы максимально сохранить в выделенных препаратах нативную организацию митохондрий, что позволяет наблюдать в них регуляцию, имевшую место в организме. Кроме того, работа проводится в микрокапле крови, что позволяет широко применять метод в клинике в отличие от обычных способов, требующих взятия биоптата ткани, что является серьезным препятствием для широкого применения в медицинских исследованиях. Также сохраняется возможность исследования ферментов гликолиза, в то время как в биохимических исследованиях цитозоль, содержащий ферменты гликолиза, отбрасывается при выделении митохондрий, и взаимодействие дыхания и гликолиза in vivo невозможно исследовать на таких препаратах. 
Одновременное определение активности СДГ и ЛДГ позволяет увидеть полную картину окислительного обмена в клетке, которая недоступна в исследованиях выделенных митохондрий.

В данном исследовании предлагается интегральный подход с использованием изолированных клеток крови для количественной оценки митохондриальных функций, что может стать предиктором прогрессирования заболевания и оценки эффективности базисной терапии.

Цель - изучение особенности дисфункции митохондриальных ферментов у детей с патологией респираторного тракта.

Научная новизна. Впервые определена значимость нарушений энергетического обмена по дисбалансу митохондриальных ферментов при респираторных заболеваниях у детей и разработан персонализированный подход к терапии.

Тема: 0479-2018-0001

НИОКТР АААА-А18-118122690045-5 


\section{МАТЕРИАЛЫ И МЕТОДЫ ИССЛЕДОВАНИЯ}

Исследование проводилось на базе детского отделения стационара, детской поликлиники и отделения иммунологии и аллергологии Больницы ПНЦ РАН, было одобрено локальным этическим комитетом БПНЦ РАН (протокол № 9 от 12.07.17) и согласовано с координационным советом научнопоисковых работ (протокол № 12 от 12.07.2017) Родители детей подписывали добровольное информированное согласие.

Уровень доказательств и сила рекомендаций каждого положения методических рекомендаций взвешены и оценены в соответствии с известными шкалами Классы рекомендаций и Уровень доказательств. Уровень доказательств А - С, классы рекомендаций I, II, IIA, IIB.

Классы рекомендаций

\begin{tabular}{|c|c|c|}
\hline $\begin{array}{c}\text { Класс } \\
\text { рекомендаций }\end{array}$ & Описание & $\begin{array}{c}\text { Предлагаемое } \\
\text { использование в практике }\end{array}$ \\
\hline I & $\begin{array}{l}\text { Доказательства и/или общее соглашение, } \\
\text { что данный метод лечения или диагностики } \\
\text { полезен и эффективен }\end{array}$ & Рекомендуется/показан \\
\hline II & $\begin{array}{l}\text { Спорные доказательства и/или расхождения } \\
\text { во мнении экспертов о пользе/эффективно- } \\
\text { сти данного метода лечения или диагностики }\end{array}$ & $\begin{array}{l}\text { Следует рассмотреть при- } \\
\text { менение данного метода }\end{array}$ \\
\hline IIA & $\begin{array}{l}\text { Доказательства/мнение экспертов склоняют- } \\
\text { ся в сторону эффективности/пользы }\end{array}$ & $-\gg-$ \\
\hline IIB & $\begin{array}{l}\text { Эффективность/польза менее подтверждены } \\
\text { доказательствами/мнением экспертов }\end{array}$ & $\begin{array}{l}\text { Применение данного ме- } \\
\text { тода может обсуждаться }\end{array}$ \\
\hline III & $\begin{array}{l}\text { Доказательства и/или общее соглашение, } \\
\text { что данный метод лечения или диагностики } \\
\text { бесполезен и неэффективен, а в отдельных } \\
\text { случаях может нанести вред }\end{array}$ & Не рекомендуется \\
\hline
\end{tabular}

Уровень доказательств

\begin{tabular}{|c|l|}
\hline Уровень доказательств & \multicolumn{1}{|c|}{ Источник данных } \\
\hline А & $\begin{array}{l}\text { Многочисленные рандомизированные клинические исследова- } \\
\text { ния и метаанализы }\end{array}$ \\
\hline В & $\begin{array}{l}\text { Отдельные или крупные рандомизированные клинические ис- } \\
\text { следования, нерандомизированные клинические исследования }\end{array}$ \\
\hline С & $\begin{array}{l}\text { Согласительное мнение экспертов и/или небольшие исследова- } \\
\text { ния, ретроспективные исследования, регистры }\end{array}$ \\
\hline
\end{tabular}


Верификация диагноза бронхиальной астмы проводилась согласно Клиническим рекомендациям МЗ РФ и GINA-2019 на основании данных клинического обследования, аллергоанамнеза, исследования крови на sIgE с пищевыми, бытовыми, эпидермальными и пыльцевыми аллергенами хемилюминесцентным методом на анализаторе Люминометр CLA-1 Hitachy (Япония) с использованием набора реагентов и тест-панелей OPTIGEN, Hitachy (Япония). Клинико-биохимическое и микробиологическое исследования проводили на базе лабораторий БПНЦ РАН по стандартным методикам, разрешенным МЗ РФ.

Обследованные дети были распределены на следующие группы:

Группа № 1 - здоровые дети - редко болеющие ОРВИ, без клинико-лабораторных признаков аллергических и других соматических заболеваний.

Группа № 2 - часто и длительно болеющие дети (ЧБД); в эту группу вошли дети, имеющие 5 и более эпизодов респираторных инфекций в году, с продолжительным течением острого периода и частыми осложнениями со стороны верхних дыхательных путей, без отягощенного аллергологического анамнеза [29; 30].

Группа № 3 - дети с БА, легкое течение с редкими обострениями - в нее вошли дети, имеющие короткие обострения только при контакте с причинно-значимыми аллергенами и не требующие применения системных ГКС, с показателями ОФВ1 более 80 \%.

Группа № 4 - дети со среднетяжелым течением БА, с частыми обострениями - с обострениями более 3-4 раз в году, вызванных причинно-значимыми аллергенами и инфекционными агентами, с ночными симптомами чаще 1 раза в неделю, с использованием в период обострения ингаляционных ГКС через небулайзер, короткими курсами, ОФВ1 от 60 до 80 \%.

Группа № 5 - дети с тяжелым течением БА, с сопутствующими заболеваниями верхних дыхательных путей и другими заболеваниями (аллергический ринит, хронический риносинусит, хронический тонзиллит, патология системы кроветворения, дискинезия желчевыводящих путей, синдром раздраженного кишечника с дисбиозом кишечной микрофлоры 2-3 степени, инфекция мочевых путей) - с частыми, более 5 раз в году, обострениями, вызванными контактом с причинно-значимыми аллергенами, инфекционными агентами и обострением сопутствующих заболеваний; с частыми ночными симптомами и ограничением физической активности, снижением ОФВ1 менее 60 \% и с применением системных ГКС коротким курсом в период обострения. В период ремиссии на фоне базисной терапии и ГКС и комбинированными ГКС показатели ОФВ1 сохранялись более 80 \%.

Все дети на момент исследования находились в стадии ремиссии более четырех недель, без признаков ОРВИ и обострения аллергического воспаления. 


\section{ИЗМЕРЕНИЕ АКТИВНОСТИ ДЕГИДРОГЕНАЗ В МАЗКАХ КРОВИ}

Для измерения функций митохондрий использован оригинальный цитобиохимический метод, разработанный в ИТЭБ РАН [25].

В данной работе описаны измеренные ЦБХ методом активности сукцинатдегидрогеназы и лактатдегидрогеназы в лимфоцитах здоровых детей разного возраста и больных астмой. Сукцинатдегидрогеназа является ключевым ферментом, характеризующим окислительную активность митохондрий в современных исследованиях [26], и отражает показатель процесса митохондриального энергообеспечения. Активность лактатдегидрогеназы, окисляющей молочную кислоту, является показателем аэробного гликолиза.

Кровь для исследования у пациентов забиралась с 8 до 10 ч, натощак. После прокола пальца скарификатором отбирали автоматической пипеткой по 8 мкл крови. Для стандартизации получаемых мазков пользовались автоматическими устройствами для изготовления мазков (V-Sampler Vision). Далее мазки высушивали на воздухе в горизонтальном положении в течение $10-15$ мин.

Свежеприготовленные мазки крови подвергали 30-секундной фиксации $60 \%$ ацетоном, забуференным 10 мM HEPES, при комнатной температу$\mathrm{pe}, \mathrm{pH} 5,2-5,4$. Затем ополаскивали дистиллированной водой и высушивали на воздухе.

Среда для измерения активности ферментов по восстановлению нитросинего тетразолия (НСТ) содержала $125 \mathrm{mM} \mathrm{KCl,} 10$ мM HEPES, 1,22 мM нитросинего тетразолия хлорида (Dudley Chemical Corporation). Для определения активности СДГ в среду добавляли 5 мМ янтарной кислоты, для ЛДГЛактат $5 \mathrm{mM}+$ МАЛ $5 \mathrm{mM}+$ НАД 0,5 мМ, $\mathrm{pH}$ 7,2 $\pm 0,05$. Использовали реактивы фирмы Sigma, за исключением НCT. Мазки инкубировали в течение 1 ч при $37^{\circ} \mathrm{C}$.

После инкубации мазки докрашивали ядерным красителем 0,05 \% нейтральным красным в течение 8 мин при комнатной температуре.

Далее мазки анализировались на микроскопе (Leica-DM 2000 с цветной фотокамерой Leica DFC 425) при увеличении х100 под масляной иммерсией. Для поиска и захвата клеток использовали специализированную компьютерную программу «Bloodrunner».

Из каждого мазка набирали 200 лимфоцитов. Активность ферментов определяли по концентрации продукта реакции - формазана в каждой клетке путем количественного морфологического анализа цветных изображений. 
Специально разработанная программа «Cell Composer» позволяла определить количество и распределение красителя в клетке на основе вычисления декомпозиции красителей по данным цветового пространства, а также базовые морфологические параметры клетки.

Статистическую обработку материала выполняли с помощью программ Statistica 10 (StatSoft, Inc.). Для проверки статистических гипотез о виде pacпределения использовали $\mathrm{W}$-тест Шапиро - Уилка. Так как показатели внутри исследуемых групп имели существенное отклонение от нормального распределения, достоверность статистических различий между группами проверяли с помощью непараметрического теста Манна - Уитни. Критерием достоверности считали уровень значимости $\mathrm{p}<0,05$. При $0,1>\mathrm{p}>0,05$ выносилось суждение о наличии статистической тенденции. Результаты представлены в виде медианы и интерквартильного размаха (Ме [25\%; 75 \%]). 


\section{РЕЗУЛЬТАТЫ ИССЛЕДОВАНИЯ И ИХ ОБСУЖДЕНИЕ. ПОКАЗАТЕЛИ ЭНЕРГЕТИЧЕСКОГО ОБМЕНА ПРИ АСТМЕ}

Результаты измерения активностей сукцинатдегидрогеназы (СДГ) и лактатдегидрогеназы (ЛДГ) у вышеперечисленных групп детей представлены на рис. 1. Для наглядности и возможности определения индивидуальных особенностей биоэнергетических показателей представлены статистически не обработанные диаграммы в виде распределения активностей у конкретных пациентов.

Из представленных данных видно, что дети из контрольной группы практически целиком находятся в зоне нормы - как по активности лактатдегидрогеназы, так и по активности сукцинатдегидрогеназы.

В группу ЧБД входили дети, не имеющие диагноза БА, и по степени тяжести заболевания из всех групп они были наиболее близки к контрольной. Но их показатели отличались от группы контроля: практически у всех наблюдается повышенная активность СДГ, активность ЛДГ у трех детей пока находится в зоне нормы, а вот у двух вышла за пределы нормы. В этой группе была обнаружена линейная обратная корреляция активности СДГ и ЛДГ - чем выше была активность ЛДГ, тем ниже СДГ. Такой зависимости не наблюдалось в остальных группах.

В следующей по тяжести заболевания группе № 3 находились дети с БА легкого течения с редкими обострениями. Половина детей имела повышенную активность СДГ и большая часть - повышенные показатели ЛДГ. В частности, три человека находились в зоне нормы по обоим показателям (пациенты № 18, 27 и 31), четверо имели гиперактивную ЛДГ при нормальной СДГ (№ 1, 2, 14, 40), двое - гиперактивную СДГ (№ 22 и 24) при нормальной ЛДГ и у пяти детей оба показателя превышали контрольные значения, но в меньшей степени, чем в предыдущей группе. Это пациенты № $3,13,17,19$ и 21 .

Более тяжелое течение болезни наблюдалось в группе № 4 (среднетяжелое течение с частыми обострениями). Все пациенты имели значительно повышенную активность СДГ, часть из них имели также ЛДГ выше нормы, а часть ЛДГ - в норме (это № 5, 6, 34 и 26). Четверо детей (№ 7, 8, 9 и 15) занимали особое положение в этой группе - имели самую высокую активность как СДГ, так и ЛДГ (плюс пациент № 4). Они отличались от остальных детей данной группы тем, что по разным причинам регулярно не получали базисную терапию. 

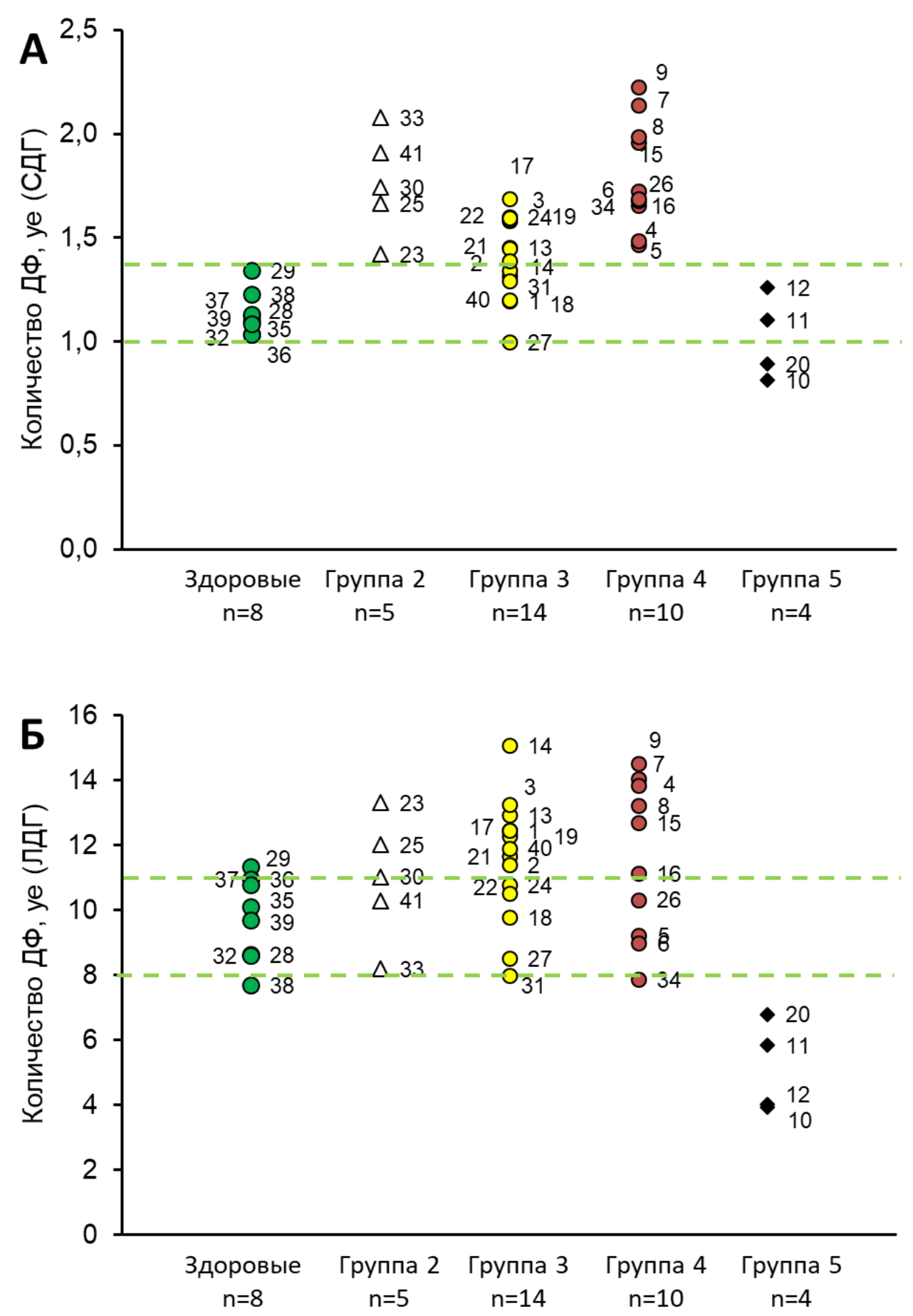

Рис. 1. Распределение показателей активности окислительного фосфорилирования (по активности СДГ-рис. 1, А) и гликолиза (по активности ЛДГ-рис. 1, Б) у обследуемых детей выделенных групп.

Зеленым пунктиром ограничена зона нормы, определенная в предыдущих исследованиях. Показаны индивидуальные показатели пациентов (среднее из 200 клеток) в каждой группе

Самая сложная по тяжести заболевания, группа № 5 (тяжелое течение с сопутствующей аллергологической и соматической патологией), кардинально отличалась по показателям энергообмена от остальных групп 
и характеризовалась снижением всех показателей по сравнению с другими группами. У двоих детей активность СДГ была снижена значительно, у двоих - оставалась на уровне контрольной группы. В то же время активность гликолиза у всех детей данной группы была значительно ниже нормы.

Если рассматривать данные каждого ребенка индивидуально, то пациент № 10, девочка восьми лет, имела тяжелое течение БА в период обострения, вызванного причинно-значимым аллергеном и инфекционным агентом, имела сопутствующий АР и заболевание протекало на фоне патологии органов кроветворения - синдром нейтрофильной лейкопении, что не давало возможности провести у неё курс аллерген-специфической иммунотерапии. Базисную терапию иГКС и топическими ГКС получала регулярно. Она имела самые низкие показатели как СДГ, так и ЛДГ.

У пациента № 20, девочки шести лет с тяжелой формой БА с частыми обострениями, вызванными причинно-значимыми аллергенами и инфекционными агентами. Девочка имела сопутствующий аллергический ринит, страдала синдромом дефицита внимания и гиперактивности, который часто выступал в качестве триггера обострений БА наряду с частыми ОРВИ. Получала адекватную базисную терапию комбинированными иГКС и топическими ГКС. У нее также наблюдались очень низкие показатели СДГ и сниженная активность ЛДГ.

Пациенты 11 и 12, мальчики 9 и 12 лет, имели сопутствующий аллергический персистирующий ринит и частые обострения, вызванные причинно значимыми аллергенами и инфекционными агентами. Тяжесть обострений была обусловлена также нерегулярным использованием препаратов базисной терапии иГКС, комбинированных и ГКС и топических ГКС из-за выраженной стероидофобии у родителей. У ребенка № 12 имелась также сопутствующая патология в виде хронического риносинусита, а у ребенка № 11 был отмечен постоянный контакт с животными, что являлось отягощающим фактором и приводило к частым тяжелым обострениям. У этих детей имелись нормальные показатели окислительного фосфорилирования, но гликолиз был значительно снижен.

Сопоставление показателей энергетического обмена с клиническими показателями представлено на рис. 2.

На рис. 2 приведены диаграммы, позволяющие сопоставить данные энергетического обмена с клиническими данными по группам. Видно, что активность окислительного фосфорилирования (активность СДГ) достоверно превышает уровень контроля во 2, 3 и 4 группах, причем во второй и четвертой группах это превышение было гораздо выше по абсолютным величинам, чем у детей в третьей группе.

В группе с максимальной тяжестью заболевания - № 5, активность СДГ имеет тенденцию к снижению по сравнению с контролем. 

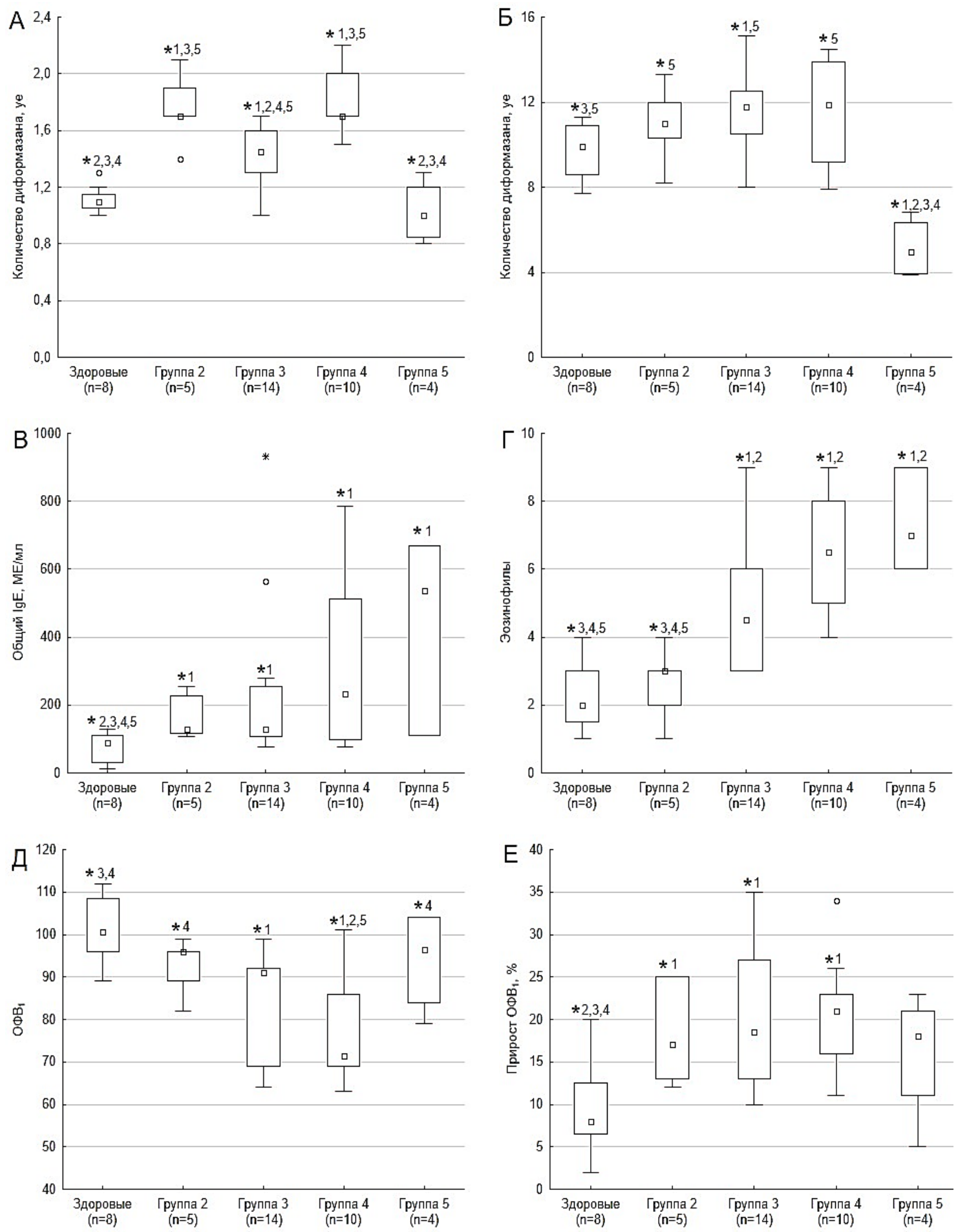

Рис. 2. Активность СДГ (А), ЛДГ (Б) и данные клинических анализов: количество $\operatorname{IgE}(B)$, эозинофилов (Г), ОФВ1 (Д) и прирост ОФВ1 (Е).

Данные представлены в виде Ме (иентральная точка) и интерквартильного размаха [25\%; $75 \%$ ] («ящики»). Над каждым боксом звездочкой отмечены отличия от соответствующих групп, $p<0,05$, критерий Манна - Уитни 
Активность ЛДГ показывала заметную тенденцию к повышению в группах 2-4, хотя достоверные отличия от контроля наблюдались только в самой многочисленной, третьей группе. А вот в группе с тяжелым течением БА - № 5 активность ЛДГ была достоверно ниже контрольной группы. Клинические показатели соответствовали тяжести заболевания. Уровень $\operatorname{IgE~во~всех~группах~детей~с~БА~и~детей~группы~ЧДБ~был~достоверно~выше,~}$ чем в контрольной группе, но между собой в этих группах достоверных отличий не было, хотя видна тенденция к увеличению у детей с более тяжелым течением БА. Количество эозинофилов в группах с БА было достоверно повышено по сравнению с группой ЧБД и контрольной. Показатели ОФВ 1 также достоверно отличались во всех группах детей с БА по сравнению с контрольной.

Не удалось выявить какой-либо корреляции биоэнергетических показателей с наличием или отсутствием приема кортикостероидных препаратов. 


\section{АНАЛИЗ ПОПУЛЯЦИЙ ЛИМФОЦИТОВ ПО АКТИВНОСТИ МИТОХОНДРИАЛЬНОГО ДЫХАНИЯ И ГЛИКОЛИЗА}

Хорошо известно, что популяция лимфоцитов гетерогенна - все клетки находятся на разных уровнях функциональной активности. Какие-то клетки могут находиться в состоянии покоя, часть клеток (высоко)активны, выполняя специфические функции. Поскольку ЦБХ анализ проводится в популяции клеток (исследуется около 200 лимфоцитов для каждого фермента каждого пациента), кроме средних цифровых значений активности ферментов можно получить данные по распределению клеток по активностям исследуемых ферментов. Эти данные приведены на рис. 3.

В группе здоровых детей основная масса клеток (43 \%) была распределена вокруг средних активностей СДГ, большая часть оставшихся клеток имела низкую активность (32 \%) и только 19 \% клеток активно использовали ОФ и имели активность СДГ выше средней. Отсутствовали высокоактивные клетки. Интересно, что у здоровых детей значительная часть клеток (16 \%) имела СДГ в неактивном состоянии, т.е. в состоянии покоя. Ситуация с гликолизом в лимфоцитах здоровых детей в основном аналогична ОФ: большая часть клеток (48 \%) имела средние значения активности, часть (20\%) имела активность выше средней. Отличия состояли в том, что наблюдалось гораздо меньше (22 \%) низкоактивных клеток, но 10 \% клеток имели очень высокую активность ЛДГ, а клеток с отсутствующим гликолизом не было выявлено.

В группе ЧБД наблюдалась качественная перестройка состава клеток по активности МХ дыхания: графики распределения показали, что увеличение энергопродукции митохондриями было обусловлено значительным увеличением средней активности СДГ (рис. 2) и происходило за счет перевода части покоящихся и низкоактивных клеток в активированное состояние. Тем не менее основная масса клеток со средней активностью не была затронута. Также эти изменения не коснулись и гликолиза: распределение клеток по активности ЛДГ в группе ЧБД не отличалось от контрольной группы.

В группе № 3 с легким течением БА распределение лимфоцитов по активности СДГ отличалось от контрольной группы аналогично группе ЧБД: увеличилось процентное содержание клеток с активностью выше средней за счет уменьшения доли неактивных и слабоактивных клеток; но эти изменения были гораздо меньшие по амплитуде, чем в группе № 2. 
Однако по активности ЛДГ: увеличивалось количество клеток с высокой и выше средней активностью ЛДГ за счет уменьшения доли клеток с низкой активностью. Неактивные по ЛДГ клетки по-прежнему отсутствовали.
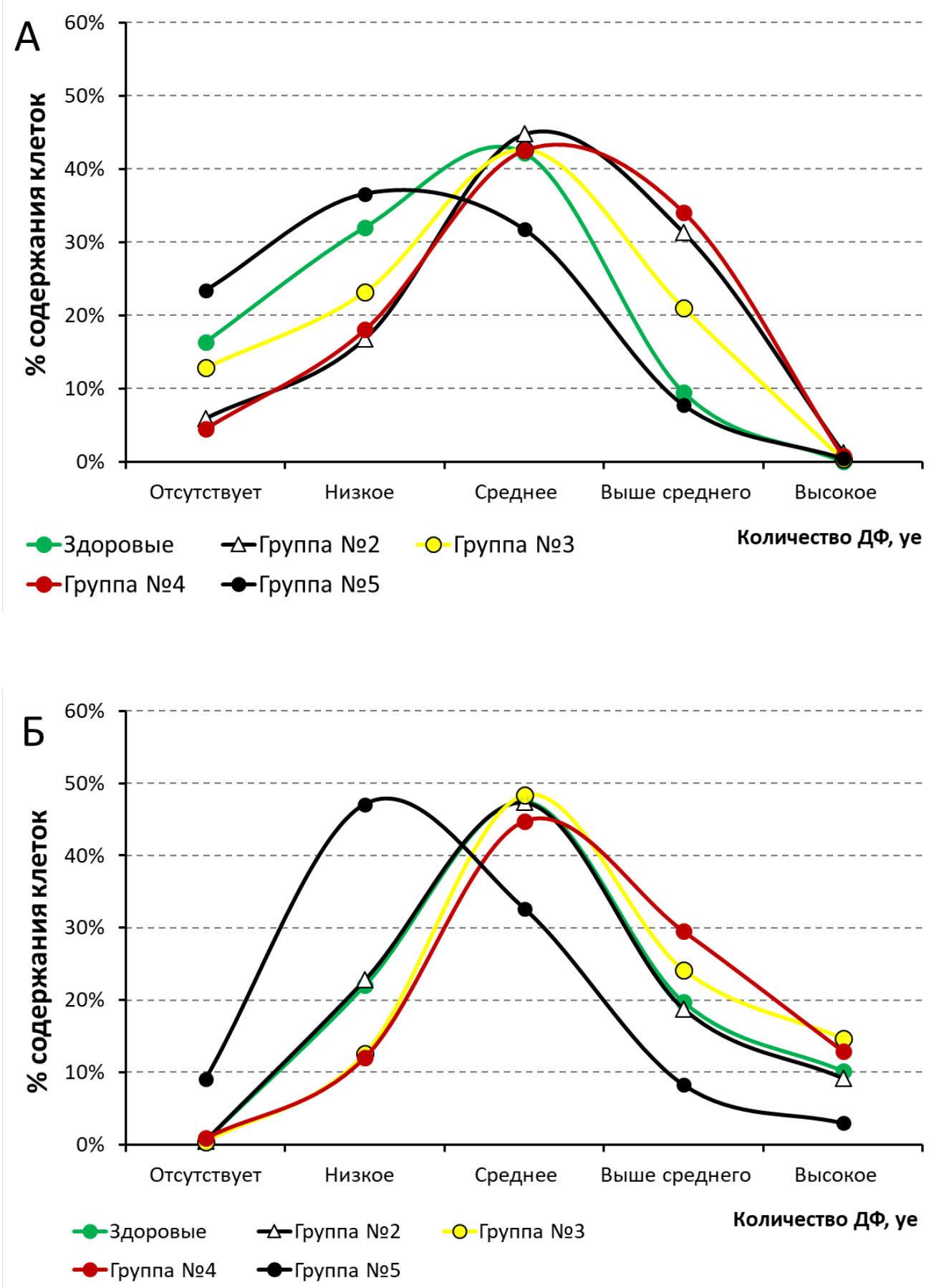

Рис. 3. Распределение клеток по субпопуляциям при анализе активности СДГ (А) и ЛДГ (Б).

У каждого ребенка вычислено процентное содержание лимфоцитов каждой степени активности ферментов в 200 исследованных клетках.

На графиках приведены средние значения по группам 
При дальнейшем увеличении тяжести заболевания - группа № 4 БА средней тяжести - была отмечена сильная активация как митохондриальной энергопродукции, так и гликолиза, как по средним значениям, так и по показателям популяционного состава: в этой группе аналогично группе ЧБД резко возрастало количество клеток с активностью выше средней, доля слабоактивных клеток снижалась. Однако эти изменения по-прежнему не затрагивали основную массу клеток со средними значениями активностей.

Кардинально меняется структура популяции лимфоцитов в группе № 5, с тяжелым течением БА: был установлен «провал» в устойчивой до этого основной массе среднеактивных клеток и сдвиг кривых распределения обоих ферментов влево: резко увеличилось количество низкоактивных клеток, параллельно со снижением доли высокоактивных клеток. Картина распределения при гликолизе характеризовалась появлением отсутствующих до этого клеток с нулевым гликолизом. 


\section{ОБСУЖДЕНИЕ}

Функции лимфоцитов периферической крови требуют наличия интегрированного метаболического механизма для возмещения энергетических потребностей при нормальной физиологии и при различных патологических процессах. При этом они могут отражать состояние биоэнергетики всего организма. По литературным данным, гетерогенная популяция лимфоцитов в норме находится в состоянии покоя и использует митохондрии (окислительное фосфорилирование - ОФ) для восполнения своих энергетических потребностей [21]. Однако, чтобы обеспечить защиту от патогенов, она должна быть способна быстро отвечать на внешние воздействия. По данным исследований [32-34], при активации лимфоцитов происходит переключение метаболического фенотипа с увеличением как гликолитических функций, так и потребления кислорода [35].

Полученные в данном исследовании результаты показали, что у здоровых детей, имеющих средние показатели окислительного фосфорилирования, оцениваемого по активности СДГ, и гликолиза, оцениваемого по активности ЛДГ, были сформированы клетками со средней активностью (43\% и 48 \% соответственно). Интересно, что около 16 \% клеток вообще не имели сукцинатдегидрогеназной активности, и не наблюдалось клеток с отсутствующим гликолизом. Также в норме 10 \% всех исследуемых клеток имели очень высокую активность гликолиза, клетки с экстремально высокой активностью СДГ отсутствовали. Таким образом, в норме в лимфоцитах здоровых детей активнее работали ферменты гликолиза, чем ОФ.

Основным ферментом, лабильно реагирующим при заболеваниях легкой степени тяжести являлась СДГ. В группе ЧБД резко возрастала активность окислительного фосфорилирования, это происходило за счет перевода пула неактивных и низкоактивных клеток в активное состояние. Активность гликолиза же увеличилась лишь у двух детей из этой группы и в среднем незначительно превышала контрольные значения. Наблюдаемое увеличение средней активности гликолитической активности, вероятно, происходило за счет внутренних резервов уже активных клеток, и дополнительный пул слабоактивных клеток не был задействован.

Важно отметить, что в группах детей с БА в процессах энергообеспечения клеток задействованы были уже оба фермента. При БА легкой степени наблюдалась гиперактивация СДГ средней степени, при которой был активирован резервный механизм энергообеспечения - гликолиз, в отличие от группы часто болеющих детей. Это может отражать благоприятную ком- 
пенсаторную активацию механизмов энергообеспечения, когда усиление митохондриального дыхания поддерживалось активным гликолизом. Этот механизм обеспечивал стабильность энергетического гомеостаза и свидетельствовал о сохранности механизмов энергообеспечения в лимфоцитах данной группе детей с легким течением заболевания [36, 37]. В более сложной по тяжести заболевания группе № 3, средний уровень повышенной активности СДГ сменялся очень сильной гиперактивацией, при этом активность гликолиза оставалась на прежнем уровне, что, возможно, вызывало развитие декомпенсированного биоэнергетического дефицита. Наблюдаемое неуклонное возрастание активности СДГ без поддержки гликолизом могло указывать на серьезные нарушения метаболического статуса в результате длительного хронического заболевания. В пользу этого утверждения свидетельствовали данные, полученные для группы № 5, детей с тяжелым течением БА. В ней установлено угнетение как митохондриальной энергопродукции, так и гликолиза, которые вряд ли можно считать нормализацией, а скорее, компенсаторным ингибированием ферментов [38; 39$]$.

Наблюдаемое нами при этом снижение пула высокоактивных клеток наряду со значительным уменьшением доли среднеактивных клеток, которая в предыдущих группах оставалась незыблемой основой стабильного функционирования, сопровождалась переходом значительной части клеток в слабоактивное состояние, а части - в дезактивированное, что свидетельствовало о декомпенсации биоэнергетических функций и истощении резервов активно функционирующих клеток и приводило к глубокому биоэнергетическому дефициту. 


\section{ЗАКЛЮЧЕНИЕ}

Полученные данные об активностях СДГ и ЛДГ в лимфоцитах периферической крови, отражающие активность митохондриального дыхания и гликолиза, а также параметры распределения клеточной популяции по активностям ферментов отражают тяжесть течения заболевания: увеличение активности ОФ, сопровождающееся поддержкой в виде активации гликолиза при заболеваниях свидетельствуют о сохранности механизмов энергообеспечения при легком и компенсированном течении заболевания, в более серьезных случаях наблюдается гиперактивация ОФ при отсутствии или угнетении процессов гликолиза; депрессия же всех изучаемых дегидрогеназ является неблагоприятным прогностическим признаком. Полученные результаты свидетельствуют о необходимости проведения дополнительно к традиционному лечению метаболической терапии, по крайней мере в группах № 4 и 5, имеющей целью стимуляцию энергопродукции в условиях глубокого биоэнергетического дефицита. По результатам обследования детей группы ЧДБ можно судить, что временное благополучие сохранялось за счет резервов и при определенных условиях это равновесие может быть нарушено, тогда у детей группы ЧДБ возрастает риск в дальнейшем сформировать аллергическое воспаление.

ЦБХ метод - минимально инвазивный и быстрый протокол для измерения клеточной энергетики имеет большой потенциал для получения важной клинической информации при конкретных условиях болезни, может обеспечить преимущества персонализированного подбора лечения и своевременной коррекции терапии. Этот подход может быть использован как основа для персонализированных измерений и количественной оценки биоэнергетического здоровья

\section{Конфликт интересов}

Конфликт интересов авторами не заявлен 


\section{СПИСОК СОКРАЩЕНИЙ}

БА - бронхиальная астма

ЧДБ - часто длительно болеющие

ЦБХ - цитобиохимический метод

СДГ - сукцинатдегидрогеназа

ЛДГ - лактатдегидрогеназа

ОФ - окислительное фосфолирирование 


\section{СВЕДЕНИЯ ОБ АВТОРАХ}

Косякова Нинель Ивановна - доктор медицинских наук, заместитель главного врача по науке, зав. отделением иммунологии и аллергологии БПНЦ РАН;

Акуленко Марина Владимировна - научный сотрудник ИТЭБ РАН, научный сотрудник БПНЦ РАН;

Сероштанова Инна Эвальдовна - зав. детским отделением поликлиники БПНЦ РАН;

Ильеня Эдуард Леонидович - зав. детским отделением стационара БПНЦ РАН;

Балясникова Виктория Сергеевна - врач иммунолог-аллерголог БПНЦ РАН;

Панкратова Елена Витальевна - зав. клинико-диагностической лабораторией БПНЦ РАН;

Андреева Людмила Александровна - зав. бактериологической лабораторией БПНЦ РАН. 


\section{ПЕРЕЧЕНЬ ОПУБЛИКОВАННЫХ РАБОТ, ВЫСТУПЛЕНИЙ, НАЛИЧИЕ ПАТЕНТА ПО ТЕМЕ МЕТОДИЧЕСКИХ РЕКОМЕНДАЦИЙ ЗА ПОСЛЕДНИЕ ТРИ ГОДА}

\section{8 год}

1. Захарченко М.В., Косякова Н.И., Кондрашова М.Н. Исследование клеток крови и митохондриальных ферментов для диагностики патологии энергетического обмена у больных бронхиальной астмой // Российский аллергологический журнал. 2018. Т. 15. Ч. 2. С. 35-37.

2. Tikhonova I.V., Kosyakova N.I., Grinevich A.A., Nadeev A.D., Chemeris N.K., Safronova V.G. Accelerated reactivity of blood granulocytes in patients with atopic bronchial asthma out of exacerbation // Immunobiology. 2018. V. 223. P. 8-17.

\section{9 год}

1. Морозова А.А., Косякова Н.И., Прохоренко И.Р. Молекулярные основы аллергии, вызванной клещами домашней пыли Dermatophagoides Pteronyssinus // Международный журнал прикладных и фундаментальных исследований. 2019. № 10. Ч. 1. С. 137-142. https://applied-research.ru/ru/article/view DOI 10.17513/mjpfi. $\mathrm{id}=12881$.

2. Косякова Н.И. Новые возможности длительно действующего бронхолитика у курящих подростков // Международный журнал прикладных и фундаментальных исследований. 2019. № 10. Ч. 2. С. 287-291. URL: https://applied-research.ru/ ru/article/view?id=12908 (дата обращения: 22.11.2019). DOI: 10.17513/mjpfi.12908.

3. Косякова Н.И. Особенность течения аллергических заболеваний у детей в городах Южного Подмосковья // Российский аллергологический журнал. 2019. № 1. C. 79-81.

4. Косякова Н.И., Андреева Л.А., Панкратова Е.В., Прохоренко И.Р. Роль инсектной аллергии в патогенезе атопической бронхиальной астмы у детей: материалы 15-го Международного междисциплинарного конгресса по аллергологии и иммунологии 22-24 мая 2019 г. // Российский аллергологический журнал. 2019. № 16 (1). С. $84-86$. 


\section{СПИСОК ЛИТЕРАТУРЫ}

1. Widlansky M.E., Wang J., Shenouda S.M. et al. Altered Mitochondrial Membrane Potential, Mass, and Morphology in the Mononuclear Cells of Humans with Type 2 Diabetes // Transl Res. 2010. No 156 (1). P. 15-25. doi:10.1016/j.trsl.2010.04.001.

2. Balu K. Chacko, philip a. Kramer, Saranya Ravi, Gloria A. Benavides, Tanecia Mitchell, Brian P. Dranka, David Ferrick, Ashwani K. Singal et al. The Bioenergetic Health Index: a new concept in mitochondrial translational research // Clinical Science. 2014. No 127. P. 367-373. doi: 10.1042/CS20140101.

3. Agrawal A. and Prakash Y.S. Obesity, metabolic syndrome, and airway disease: a bioenergetic problem? // Immunol Allergy Clin North Am. 2014. No 34 (4) P. 785-796. doi: 10.1016/j.iac.2014.07.004.

4. Nunnari J. and Suomalainen A. Mitochondria: in sickness and in health. Cell. 2012. No 148 (6). P. 1145-1159.

5. Irving B.A., Nair K.S. Aging and diabetes: mitochondrial dysfunction // Curr Diab Rep. 2007. No 7. P. 249-251. [PubMed: 17686399].

6. Libby P., Ridker P.M., Maseri A. Inflammation and atherosclerosis // Circulation March. 2002. No 5. P. 105 (9). P. 1135-1143. [PubMed: 11877368].

7. Mancuso M., Calsolaro V., Orsucci D. et al. Mitochondria, cognitive impairment, and Alzheimer's disease // Int J Alzheimers Dis 2009. 2009. pii951548.

8. Lim K.L., Ng X.H., Grace L.G. et al. Mitochondrial dynamics and Parkinson's disease: focus on parkin // Antioxid Redox Signal. 2012. No 16. P. 935-949.

9. Suzanne M. Cloonan and Augustine M.K. Choi. Mitochondria in lung disease // J Clin Invest. 2016. No 126 (3). P. 809-820. doi: 10.1172/JCI81113.

10. Marina Ostroukhova, Nicholas Goplen, Md Zunayet Karim, Lidia Michalec, Lei Guo, Qiaoling Liang, and Rafeul Alam. The role of low-level lactate production in airway inflammation in asthma // Am J Physiol Lung Cell Mol Physiol. 2012. No 302. P. L300-L307. doi: 10.1152/ajplung.00221.2011.

11. Tingting Fang \& Manni Wang \& Hengyi Xiao \& XiaweiWei. Mitochondrial dysfunction and chronic lung disease. Fang, Tingting \& Wang, Manni \& Xiao, Hengyi \& Wei, Xiawei. Mitochondrial dysfunction and chronic lung disease // Cell Biology and Toxicology. 2019. Vol. 35. P. 493-502. doi: 10.1007/s10565-019-09473-9.

12. Stefan W. Ryter, Ivan O. Rosas, Caroline A. Owen, Fernando J. Martinez, Mary E. Choi, Chun Geun Lee, Jack A. Elias 4,5, and Augustine M. K. Choi. Mitochondrial Dysfunction as a Pathogenic Mediator of Chronic Obstructive Pulmonary Disease and Idiopathic Pulmonary Fibrosis // Ann Am Thorac Soc. 2018. No 15 (Suppl 4). P. S266S272. doi: 10.1513/AnnalsATS.201808-585MG.

13. Kenneth P. Hough, Jennifer L. Trevor, John G. Strenkowski, Yong Wang, Balu K. Chacko et al. Exosomal transfer of mitochondria from airway myeloid-derived regulatory cells to T cells // Redox Biology 18. 2018. P. 54-64. doi: 10.1016/j. redox.2018.06.009.

14. Barnes P.J. Immunology of asthma and chronic obstructive pulmonary disease, Nat. Rev // Immunol. 2008. No 8. P. 183-192. 
15. A. Ray, A. Khare, N. Krishnamoorthy, Z. Qi, P. Ray, Regulatory T cells in many flavors control asthma // Mucosal Immunol. 2010. No 3. P. 216-229.

16. Lerner C.A., Sundar I.K., and Rahman I. Mitochondrial redox system, dynamics, and dysfunction in lung inflammaging and COPD // Int J Biochem Cell Biol. 2016. No 81(Pt B). P. 294-306.

17. Agarwal A.R., Yin F., Cadenas E. Metabolic shift in lung alveolar cell mitochondria following acrolein exposure // Am. J. Physiol. Lung Cell Mol. Physiol. 2013. No 305. P. L764-L773.

18. Нарциссов Р.П. Прогностические возможности клинической цитохимии. М.: Сов. педиатрия, 1984.

19. Нарциссов Р.П. Митохондриальные болезни. Взгляд цитохимика. М.: Медицина, 1999.

20. Philip A. Kramer, Saranya Ravi, Balu Chacko, Michelle S. Johnson, Victor M. Darley-Usmar. A review of the mitochondrial and glycolytic metabolism in human Platelets and leukocytes: Implications for their use as bioenergetics biomarkers // Redox Biology. 2014. No 2. P. 206-210. doi: 10.1016/j.redox.2013.12.026.

21. Stefan Krauss, Martin D. Brand, and Frank Buttgereit. Signaling Takes a Breath New Quantitative Perspectives on Bioenergetics and Signal Transduction // Immunity. 2001. Vol. 15. P. 497-502.

22. Balu K Chacko, Philip A Kramer, Saranya Ravi, Michelle S Johnson, Robert W Hardy, Scott W Ballinger and Victor M Darley-Usmar. Methods for defining distinct bioenergetic profiles in platelets, lymphocytes, monocytes, and neutrophils, and the oxidative burst from human blood // Laboratory Investigation. 2013. No 93. P. 690-700. doi: 10.1038/labinvest.2013.53.

23. Jones N., Piasecka J., Bryant A.H., Jones R.H., Skibinski D.O.F., Nigel. J. Francis and Thornton C.A. Bioenergetic analysis of human peripheral blood mononuclear cells // Clinical and Experimental Immunology. 2015. No 182. P. 69-80. doi: 10.1111/ cei.12662.

24. Justin I. Odegaard1 and Ajay Chawla. The Immune System as a Sensor of theMetabolic State // Immunity. 2013. No 38. P. 644-654. doi: 10.1016/j.immuni.2013.04.001.

25. Кондрашова М.Н., ОАО ДИОД, Захарченко М.В., Хундерякова Н.В., Маевский Е.И. ИТЭБ РАН. Патент Российской Федерации. Цитобиохимический способ определения активности сукцинатдегидрогеназы, окисления эндогенной янтарной кислоты, сигнального действия микромолярных концентраций янтарной кислоты, его применение для количественной оценки уровня адренергической регуляции в организме, среда и набор для осуществления способа. 20.08.09 Бюллетень Роспатента № 23.

26. Zakharchenko M.V., Zakharchenko A.V., Khunderyakova N.V., Tutukina M.N., Simonova M.A., Vasileva A.A., Romanova O.I., Fedotcheva N.I., Litvinova E.G., Maevskiy E.I., Zinchenko V.P, Berezhnov A.V., Morgunov I.G., Gulayev A.A, Kondrashova M.N. Burst of succinate dehydrogenase and $\alpha$-ketoglutarate dehydrogenase activity in concert with the expression of genes coding for respiratory chain proteins underlies short-term beneficial physiological stress in mitochondria // Int. J. Biochem. Cell Biol. 2013. No 45. P. 190-200.

27. Кондрашова М.Н., Захарченко М.В, Хундерякова Н.В., Литвинова Е.Г., Федотчева Н.И., Романова О.Р., Шварцбурд П.М. Что дает врачу определение 
функций митохондрий в лимфоцитах больного. В коллективной монографии: Инновационные методы диагностики в медицине / Ред. В.П. Волков. СибАК. Новосибирск, 2013. 149 с. С. 10-58.

28. Косякова Н.И., Захарченко М.В., Шварцбурд П.М., Кондрашова М.Н. Исследование ферментов лимфоцитов крови с целью разработки чувствительного метода диагностики и коррекции патологии катаболизма и анаболизма при хронической обструктивной болезни легких у пожилых больных // Международный журнал прикладных и фундаментальных исследований. 2018. № 11. С. 277-282. doi: 10.17513/mjpfi.12490 SSN 1996-3955.

29. Альбицкий В.Ю., Баранов А.А. Часто болеющие дети. Клинико-социальные аспекты, пути оздоровления. Саратов: Изд-во Саратовского мед. университета, 1986. 45 c.

30. Романцов М.Г., Ершов Ф.И. Часто болеющие дети. Современная фармакотерапия. М.: ГЭОТАР-Медиа, 2006. 190 с.

31. Rustin P., Munnich A. and Rotig A. Succinate dehydrogenase and human diseases: new insights into a well-known enzyme // Eur J Human Genetics. 2002. Vol. 10. P. 289-291.

32. Erika L. Pearce, and Edward J. Pearce. Metabolic Pathways in Immune Cell Activation and Quiescence // Immunity. 2013. No 38. P. 633-643. doi: 10.1016/j. immuni.2013.04.005.

33. Gerritje J.W. van der Windt \& Erika L. Pearce. Metabolic switching and fuel choice during T-cell differentiation and memory development // Immunological Reviews. 2012. Vol. 249. P. 27-42.

34. Noga Ron-Harel, Arlene H. Sharpe, Marcia C. Haigis. Mitochondrial Metabolism in T Cell Activation and Senescence: A Mini-Review // Gerontology. 2015. No 61. P. 131-138. doi: 10.1159/000362502.

35. Andrew N. Macintyre and Jeffrey C. Rathmell. Activated lymphocytes as a metabolic model for carcinogenesis // Cancer Metab. 2013. No 1 (1). P. 1-5. doi:10.1186/2049-3002-1-5.

36. Erika L. Pearce, Maya C. Poffenberger, Chih-Hao Chang, and Russell G. Jones. Fueling Immunity: Insights into Metabolism and Lymphocyte Function // Science. 2013. No 342 (6155). doi:10.1126/science.1242454.

37. Lunt S.Y., Vander Heiden MG: Aerobic glycolysis: meeting the metabolic requirements of cell proliferation // Annu Rev Cell Dev Biol. 2011. No 27. P. 441-464.

38. Кондрашова М.Н., Григоренко Е.В. Стресс на уровне митохондрий // Журнал общей биологии. 1984. Т. 46. С. 516-526.

39. Кондрашова М.Н. и др. Субстратно-гормональная система регуляции физиологического состояния. Условия ее выявления. Использование в практике. Горизонты биофизики. Пущино: ОНТИ НЦБИ, 2003. С. 147-154. 


\section{Научное издание}

Косякова Нинель Ивановна, Акуленко Марина Владимировна, Сероштанова Инна Эвальдовна,

Ильеня Эдуард Леонидович, Балясникова Виктория Сергеевна, Панкратова Елена Витальевна, Андреева Людмила Александровна

\section{ИНДИВИДУАЛЬНЫЕ ОСОБЕННОСТИ ТКАНЕВОГО ЭНЕРГООБМЕНА И ИХ РОЛЬ В РАЗВИТИИ МИТОХОНДРИАЛЬНОЙ ДИСФУНКЦИИ ПРИ ЗАБОЛЕВАНИЯХ РЕСПИРАТОРНОГО ТРАКТА У ДЕТЕЙ}

Методические рекомендации

по внедрению результатов научно-поисковой работы

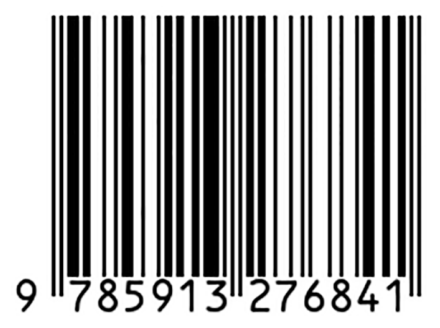

Технический редактор Доронкина Е.Н.

Подписано в печать 29.04.2021.

Бумага офсетная.

Гарнитура Times New Roman.

Формат $60 \times 84$ 1/8.

Печать трафаретная. Печ. л. 3,2.

Тираж 500 экз. Заказ № 016-21.

Отпечатано в типографии ИД «Академия Естествознания», 440026, г. Пенза, ул. Лермонтова, 3 